\title{
FLAVONOIDS OF Atraphaxis spinosa. I
}

T. K. Chumbalov, M. M. Mukhamed'yarova, and I. S. Chanysheva

UDC 547.972

From the leaves of Atraphaxis spinosa L. growing in the Alma-Ata region of the Kazakh SSR, we have isolated the combined flavonoids, consisting of 14 substances, by methanol extraction.

Chromatography on Kapron of the methanolic extract yielded a flavone glycoside (I) with $\mathrm{mp} 179-181^{\circ} \mathrm{C}$ in the form of lemon-yellow needles (from aqueous methanol), $R_{f} 0.40$ [butan-1-ol-acetic acid-water $(4: 1: 5)], 0.34$ ( $2 \%$ acetic acid), $[\alpha]_{D}-167.2^{\circ}$ (c 0.16 , methanol).

The IR spectrum of substance I shows absorption bands at $\left(\mathrm{cm}^{-1}\right) 3360$ (hydroxy groups), 1669 carbonyl of a $\gamma$-pyrone bound by a hydrogen bond with a 5-OH), 1600, 1580, 1510 (benzene ring), 2970, 2850 (methoxy groups), and 890, which is characteristic for the $\beta$ form of the pyranose ring of a sugar $[1,2]$.

UV spectrum of the glycoside with additives: $\lambda \max 338,260 \mathrm{~nm}\left(\mathrm{C}_{2} \mathrm{H}_{5} \mathrm{OH}\right), 410,260\left({ }^{+} \mathrm{C}_{2} \mathrm{H}_{5} \mathrm{ONa}\right), 340$, $\left.266\left(+\mathrm{CH}_{3} \mathrm{COONa}\right), 370,266\left(+\mathrm{H}_{3} \mathrm{BO}_{3}\right), 390,260 \mathrm{~nm}(+\mathrm{ZrOCl})_{2}\right)[13]$.

UV spectrum of the aglycone: $\lambda \max 342,266 \mathrm{~nm}\left(\mathrm{C}_{2} \mathrm{H}_{5} \mathrm{OH}\right), 365,266\left(+\mathrm{CH}_{3} \mathrm{COONa}+\mathrm{H}_{3} \mathrm{BO}_{3}\right), 387,275$ $\left(+\mathrm{C}_{2} \mathrm{H}_{5} \mathrm{ONa}\right), 365,273\left(+\mathrm{ZrOCl}_{2}\right), 365,268 \mathrm{~nm}$ ( + citric acid).

The acid and enzymatic hydrolysis of the substance gave the aglycone $(68 \%)$ and L-rhamnose. The aglycone has mp $306-308^{\circ} \mathrm{C}$ and $\mathrm{R}_{f} 0.25\left[\mathrm{C}_{6} \mathrm{H}_{6}-\mathrm{CH}_{3} \mathrm{COOH}-\mathrm{H}_{2} \mathrm{O}\right.$ (125:72:3)] (1), 0.75 [HCOOH $-\mathrm{CH}_{3} \mathrm{COOH}-$ $\mathrm{H}_{2} \mathrm{O}(2: 10: 3)$ ] (2), and 0.62 [butan-1-ol- $-\mathrm{CH}_{3} \mathrm{COOH}-\mathrm{H}_{2} \mathrm{O}(4: 1: 5)$ ] (3).

Microanalyses showed the presence of one methoxy group both in the glycoside and in the aglycone.

The demethylation of the aglycone [4] gave luteolin with $\mathrm{R}_{f} 0.53$ (1), 0.66 (2), and 0.20 (3), identified by paper chromatography with a reference sample.

Thus, on the basis of chemical and spectral studies, substance I has been characterized as 7-Omethyl-4'-O- $\beta$-L-rhamnopyranosylluteolin, and we have called it spinoside.

\section{LITERATURE CITED}

1. L. H. Briggs and L. D. Colebrook, Spektrochimica Acta, 18, 938 (1962).

2. I. P. Kovalev and E. V. Titov, Infrared Absorption Spectra of Some Groups of Natural Compounds. Atlas of Spectra [in Russian], Khar'kov (1966), p. 9.

3. V. I. Litvinenko and N. P. Maksyutina, KhPS [Chemistry of Natural Compounds], 420 (1965).

4. L. I. Deryugina, KhPS [Chemistry of Natural Compounds], 315 (1966) .

Kirov Kazakh State University. Translated from Khimiya Prirodnykh Soedinenii, No. 5, p. 626, September-October, 1970. Original article submitted May 5, 1970.

- 1973 Consultants Bureau, a division of Plenum Publishing Corporation, 227 West 17th Street, New York, N.Y. 10011. All rights reserved. This article cannoi be reproduced for any purpose whatsoever without permission of the publisher. A copy of this article is available from the publisher for $\$ 15.00$. 